JURNAL AL BAYAN: JURNAL JURUSAN PENDIDIKAN BAHASA ARAB

p-ISSN 2086-9282 | e-ISSN 2549-1229

\title{
The Characteristics of Teaching Material Arabic Speaking Skills in Higer Education
}

\author{
Puti Zulharby ${ }^{1 *}$, Yumna Rasyid ${ }^{2}$, Nuruddin ${ }^{3}$ \\ ${ }^{1}$ Language Education Study Program Universitas Negeri Jakarta, Indonesia \\ ${ }^{2}$ Language Education Study Program Universitas Negeri Jakarta, Indonesia \\ ${ }^{3}$ Arabic Education Study Program Universitas Negeri Jakarta, Indonesia
}

\footnotetext{
Article History:

Received : September 10, 2019

Revised : October 20, 2019

Accepted : November 25, 2019

Published : December 01, 2019
}

Keywords:

Communication; Developing;

Difficulty; Needs; Material; Phonetic

*Correspondence Address: puti.zulharby@unj.ac.id

\begin{abstract}
Research objective is to providing an insight into the characteristics of Arabic language teaching materials in higher education in Indonesia. This research was conducted by examining a variety of literature relating to teaching materials and Arabic speaking skills. The research method applied survey, involving 97 students from the Arabic Language Education Study Program in several universities in Indonesia and structured interviews with lecturers who supported Arabic speaking skills. The procedure taken are 1) reading literature related to Arabic speaking teaching materials and teaching Arabic speaking skills, 2) observing the learning process of speaking skills at several Arabic Language Education Study Programs, 3) determining the type of survey, 4) determining the sample target, 5) preparing instruments for analyzing the needs of students, 6) preparing structured interview instruments for lecturers, 7) analyzing survey results, 8) translating survey result. The results of this study, teaching materials from Middle East has led to the emergence of gaps in achieving Arabic language skills for beginners, such as the lack of phonetic aspects being taught, monotonous forms of practice, directing students to memorize, and types of dialogue that are not in accordance with student culture in Indonesia. The characteristics of teaching materials that are suitable for use in Arabic language skills are divided into goals, phonetics, themes, social culture, exercises, steps and visualization.
\end{abstract}

\section{Introduction}

The development of curriculum and information technology in the learning process in higher education is rolling more and more quickly. Through information technology facilities, students currently have abundant and easily available learning resources. Of course, this needs to be balanced with the renewal of the knowledge and skills of lecturers. One of them is the ability of lecturers to develop teaching materials as a source of learning because basically, lecturers are conveyers of ideas and who "force" students to learn. 
Wahab explained, there are at least four orientations towards the direction of the Arabic language curriculum in Indonesia, namely religious orientation, academic orientation, professional orientation, and economic orientation. ${ }^{1}$ Academically oriented universities, the learning process aims to understand the Arabic language, translation and Arabic language skills such as listening, speaking, reading and writing. This orientation places Arabic as a scientific discipline or object of study that must be mastered academically. In higher education institutions that have Arabic Language Education Study Programs, speaking skills are used as a benchmark for the success of their graduates.

Arabic teaching materials that are currently developing and widely used to learn Arabic speaking skills for beginners at universities in Indonesia are teaching materials published by the Middle East. Not yet found so many teaching materials Arabic speaking skills that come from the results of development. The majority of State Universities in Indonesia use teaching materials published by the Middle East such as books $\mathrm{Al}$ Arabiyah Baina Yadaik (ABY), Al-Arabiyah lil 'Alam (ALA) and Al-Arabiyah lin Nasyiin (ALIN). ${ }^{2}$ Book ABY was published by Mu'assasah al Waqf al Islami, Riyadh Saudi Arabia, in 1424 H / 2003 M. The ALA book was published by Wizarat Ta'limil 'Aliy, King Saud University of Riyadh, Saudi Arabia, in 1431 H / 2010 M. And book ALIN was published by Idarat al-Kutub al-Madrasiyyah, Wizarat al-Ma'arif, Saudi Arabia, in $1403 \mathrm{H} / 1983 \mathrm{M}$.

Teaching students to speak is totally different from teaching them to speak in another language. ${ }^{3}$ More specifically, the needs of beginner Arabic students are the ability to pronounce Arabic sounds, especially sounds that have no equivalent in Indonesian, the ability to pronounce sentences with clear articulation, and the ability to speak using the right intonation and rhythm. ${ }^{4}$ This need arises because the three instructional materials above provide insufficient portions of the phonetic accuracy of

${ }^{1}$ Muhbib Abdul Wahab, 'Standarisasi Kurikulum Pendidikan Bahasa Arab Di Perguruan Tinggi Keagamaan Islam Negeri', Jurnal Pedidikan BAhasa Arab Dan Kebahasaaraban, 3.1 (2016), 32-51 <https://doi.org/http://dx.doi.org/10.15408/a.v3i1.3187>.

${ }^{2}$ Kholisin, 'Pembelajaran Kalam Berbasis Phonetic Accuracy Untuk Meningkatkan Kemampuan Berbicara Bahasa Arab’, Jurnal Bahasa, Sastra, Seni Dan Pengajaran, 43.2 (2015), 143-53.

3 Basma Ahmad Sedki Dajani, Salwa Mubaideen, and Fatima Mohammad Amin Omari, 'Difficulties of Learning Arabic for Non-Native Speakers', Procedia - Social and Behavioral Sciences, 114 (2014), 919-26 <https://doi.org/10.1016/j.sbspro.2013.12.808>.

4 Yumna Rasyid and Puti Zulharby, 'Developing Syllabus of Arabic Language Productive Competence Based on Content Language Integrated Learning (Clil)', Ijer - Indonesian Journal of Educational Review, 4.1 (2017), 153 <https://doi.org/10.21009/ijer.04.01.15>. 
both segmental and suprasegmental aspects and their variations because this teaching material from the Middle East is used by foreign speakers/students who are learning Arabic in the Middle East region. Although most of the teaching material from the Middle East has a subtitle that reads 'arabiyyah li ghair an-nathiqin biha atau silsilatun $f i$ ta'limi lughatil 'arabaiyah lin nathiqhina billugatin ukhra (learning Arabic for foreign speakers), who is meant by foreign speakers is still common, does not refer to certain countries or nations. While each country has a different language and cultural characteristics. ${ }^{5}$

Ali Muhammad Al-Qasimy, a linguist and Arabic language instructor for foreigners, at the University of Riyadh, suggested that Arabic textbooks for teaching Arabic for foreigners like Indonesians must include some material, namely reading (Muthala'ah), rule (Qawa'id) and exercises (Tadribat). ${ }^{6}$ In terms of reading (Muthala'ah), the three teaching materials above have advantages in the forms of communication commonly used in the Middle East. The opinion that language is culture needs to be another consideration in developing teaching materials. Not all cultures in Indonesian can be implemented in Arabic, and vice versa.

In terms of the exercises (Tadribat) contained in teaching materials, the form of exercise in the three teaching materials above generally leads students to imitate and memorize. Memorization is not speaking skill, but rote learning is only a supporter of vocabulary for students to be able to speak. Memorization relies on sharp memories, while speaking relies on the effort to produce words into sentences and efforts to express what is in the mind using language that can be understood. Arabic language lead, welloff with words and vocabularies. ${ }^{7}$ Vocabulary mastery can affect the success of learning to speak Arabic for foreign speakers. ${ }^{8}$ But what is memorized is not the dialogue, but the

\footnotetext{
${ }^{5}$ Kholisin.

${ }^{6}$ Roviin Roviin, 'Analisis Buku Teks Al 'Arabiyah Li Al Nasyi'in Karya Mahmud Ismail Shini, Dkk', Jurnal Al Bayan: Jurnal Jurusan Pendidikan Bahasa Arab, 10.01 (2018), 36-53 <https://doi.org/10.24042/albayan.v10i01.2594>.

7 Ashraf M. Zedan and others, 'The Role of Language in Education: Arabic as Case Study', $\begin{array}{llllll}\text { Procedia - Social and Behavioral Sciences, } 70 & \text { (2013), } & 1002-8\end{array}$ <https://doi.org/10.1016/j.sbspro.2013.01.151>.

8 Muhammad Tunde Yaqub, 'Developing Speaking Skill in Arabic Learners: A Proposal for Integration of Product and Proces Approaches', European Scientific Journal, 8.29 (2012), 140-49 <https://doi.org/http://dx.doi.org/10.19044/esj.2012.v8n29p\%25p>.
} 
vocabulary. What often happens during practice in classrooms is that less competent students are marked by memorizing expressions and the number of mistakes made. ${ }^{9}$

In addition to minimizing memorization, teaching materials in Arabic speaking skills will be better if you pay attention to sociocultural elements and direct experience. ${ }^{10}$ Speaking is a high level of learning anxiety among beginner students. Willingness to Communicate (WTC) is psychological readiness in using language, namely speaking is the best opportunity to encourage the willingness and courage of students to communicate. ${ }^{11}$ For this reason, the learning environment plays an important role in improving the ability to speak Arabic. Theory of Behaviorism (Skinner) states that humans are born with the brain such as tabula rasa or blank slate, where this blank slate will be filled by the surrounding environment. In minimizing efforts to memorize and reduce student anxiety, the teaching materials for speaking Arabic for beginners should provide themes that are close to the context of student communication.

Based on the explanation above, developing a model of teaching materials in Arabic speaking skills must be based on the trust of lecturers using teaching materials, because this trust will have a direct impact on learning success. ${ }^{12}$ Seeing the urgency of teaching materials in Arabic speaking skills as described above, teaching materials published in the Middle East that are generally used in Indonesia have not been updated, while the development of curriculum and information technology forms a gap between teaching materials and learning objectives. This gap makes the learning process seem obsolete. Then, to fill the gaps, this study seeks to provide a view of the characteristics that can be used as guidelines for the development of teaching materials in Arabic speaking skills in higher education in Indonesia.

\footnotetext{
${ }^{9}$ Kamarulzaman Abd. Ghani and others, 'Development of a Learning Module on Arabic Language Skills Outside of the Classroom', Procedia - Social and Behavioral Sciences, 18 (2011), 154-62 <https://doi.org/https://doi.org/10.1016/j.sbspro.2011.05.023>.

10 Muspika Hendri, 'Pembelajaran Keterampilan Berbicara Bahasa Arab Melalui Pendekatan Komunkatif', POTENSIA: Jurnal Kependidikan Islam, $3.2 \quad$ (2017), 196 <https://doi.org/10.24014/potensia.v3i2.3929>.

${ }^{11}$ Mohammad-Hadi Mahmoodi and Ismail Moazam, 'Willingness to Communicate (WTC) and L2 Achievement: The Case of Arabic Language Learners', Procedia - Social and Behavioral Sciences, 98 (2014), 1069-76 <https://doi.org/https://doi.org/10.1016/j.sbspro.2014.03.518>.

${ }^{12}$ Majid Amerian and Sajjad Pouromid, 'Language Teachers' Beliefs on Materials Use And Their Locus Of Control: Case-Studies From Iran And Japan', International Journal of Applied Linguistics, 7.3 (2018) <https://doi.org/http://dx.doi.org/10.17509/ijal.v7i3.9808>.
} 


\section{Theoretical Support}

\section{Principles of Development of Arabic Language Teaching Materials}

Developing Arabic teaching materials in Indonesia has its peculiarities. If the teaching materials available cannot meet the needs of learning Arabic, a lecturer needs to develop Arabic teaching materials that are suitable to the needs of students. This effort must certainly pay attention to the development of the curriculum in Indonesia, and the development of Arabic language trends in the user countries.

Designing and developing teaching materials should be done systematically so that they can have the benefit to be able to support the learning process. In developing teaching materials, the role of lecturers is to determine, design and arrange teaching materials that can influence the success of the learning process and the learning through a teaching material. ${ }^{13}$ Organizing teaching materials involves five simultaneous processes, namely: 1) Determine organizing principles that can encourage learning for the better; 2) identify units of learning material based on organizing principles; 3) sort the units; 4) determine the language content and skills to be achieved from each unit; 5) organize content in each unit. ${ }^{14}$ These five processes, do not have to be in order, the lecturer can work on the content and organization of the unit or flow first before deciding how to order the units as a whole.

\section{Arabic speaking skills}

Speaking in Arabic is an art of speaking. This language art consists of 4 (four) elements, namely sound, language, thought and performance. ${ }^{15}$ Two things need to be distinguished in learning to speak, namely pronunciation and speaking exercises. Generally, an error occurs where the lecturer considers that learning has achieved its objectives when students have been able to recite dialogues according to the text. This activity was not successful, because it was still at the level of pronunciation practice. Actual speaking exercises by increasing the practice of verbal expression practice the ability to hear and speak while communicating. ${ }^{16}$

\footnotetext{
${ }^{13}$ Andi Prastowo, Panduan Kreatif Membuat Bahan Ajar Inovatif (Yogyakarta: Diva Press, 2016).

${ }^{14}$ Kathleen Graves, Designing Language Courses: A Guide for Teachers (Canada: Heinle \& Heinle Publishers, 2000). (2003.

${ }^{15}$ Muhammad Rajab Fadhlullah, الاتجاهات التربيوية المعاصرة في تدريس اللغة العربية, ed. by عالم الكتب (القاهرة,

مكة المكرمة: ) تعليم اللغة العربية لناطقين بالغة الأخرى: أسوسه، مداخله، طروق تدريسه Mahmud Kamil Al-Naqah,

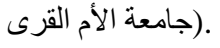


Some principles of learning to speak using Arabic, among others: 1) learning must be integrated with the language curriculum, teaching materials, activities undertaken by students on campus; 2) there is a link between learning Arabic speaking skills with the real life of students out of campus: such as social activities, getting acquainted and others; 3 ) practice to be scientifically responsible for what is said; and 4) developing student thinking frameworks. ${ }^{17}$

Several factors can affect the ability to speak in Arabic students in Indonesia, including 1) Age and Maturity Factors. Krashen, Long, and Scarcella (1982) argue that a child who starts learning a second language at an early age will achieve higher abilities than those who start after adulthood. Adult skills in learning Arabic often seem horizontal, this phenomenon is usually called "fossilization" (permanent halt to second language development). ${ }^{18}$ This phenomenon shows that as we get older, it can affect the ability to produce and speak the target language like the native speaker. 2) Listening and listening skills. When listening, students must understand the text by retaining information in memory, integrating it with sentences afterward, and continuously adjusting their understanding of what they hear from incoming knowledge and information. ${ }^{19}$ 3) Socio-Cultural. When speaking, one must know how language is used in a social context, knowing the rules that each language has its own rules for when, how and for what speech is delivered. Values and beliefs in certain cultures create traditions and social structures that bind people, which are presented in their language. ${ }^{20}$ Because the influence or interference of these cultural norms sometimes makes it difficult for Arabic students to choose the appropriate form in certain situations. 4) Affective Side. Associated with emotions, self-confidence, empathy, learning anxiety, learning attitudes and learning motivation. Learning a second language is a complex matter related to student anxiety, feelings of anxiety, frustration, doubt in speaking and sometimes fear of speaking a foreign language in public, especially in the presence of native speakers. Quite extreme anxiety sometimes occurs when a student feels like his tongue is tied (tongue-tied) in the sense that students lose words in unexpected situations. Not like children, adults tend to be concerned with other people's judgments about their speaking

\footnotetext{
${ }^{17}$ Samir Syarif Istitih, ‘علم اللغة التعلمي, pp. 141-42.

${ }^{18}$ Jack C. Richard and Willy A Renandya, Methodology in Language Teaching: An Anthology of Current Practice (New York: Cambridge University Press, 2002).

19 D.J Mendelsohn and J Rubin, A Guide for The Teaching Of Second Language Listening (Dominie Press, 1995).

${ }^{20}$ Richard and Renandya.
} 
abilities. So adults are more careful not to make mistakes when talking because. So it is very clear that an adult's sensitivity to making mistakes in speaking will have an impact on the judgment of others and the opinions of others.

In learning Arabic as a second language, students not only need to understand the linguistic elements but also how their speech can be received in different situations and interactions. Several competency components underlie speaking effectiveness, namely grammatical competence, discourse competence, sociolinguistic competence, and strategic competence. ${ }^{21}$ 1) Grammatical Competence, including expertise in grammar (morphology, syntax), vocabulary, and mechanics. 2) Competence of Discourse, in communication, both productive and understanding/receptive, requires the ability to understand and extend the discourse process, formulating a representation of the meaning of the referent in the previous sentence and the next sentence. Therefore, the effective conversation must be able to express ideas, show time relations, show cause and effect, and emphasize. So with this, Arabic students can manage their turn in communication. 3) Sociolinguistic Competencies. Knowledge of languages alone is not enough to prepare Arabic students to be able to use Arabic effectively. Arabic students must have competencies that involve the social and cultural knowledge of the target language users. Arabic students must obtain rules and norms that govern the right time and speech realization. $^{22}$ 4) Competency Strategy is the way students use and play their language to meet communicative goals, this competency may be the most important of all elements of communicative competence. In speaking Arabic, strategic competence refers to the ability to know when and how to take turns, how to keep the conversation going, and how to end the conversation. ${ }^{23}$

\section{Method}

The research method uses a survey method, which is an information-gathering technique that is done by compiling a list of questions asked to respondents in the form of samples from a population. The purpose of survey research is to find out a general description of the characteristics of the population. In survey research, researchers examine the characteristics of causal relationships between variables without the

\footnotetext{
${ }^{21}$ Richard and Renandya.

22 Mahmud Manshur, الإستماع و الحوار فنون المقابلة المثالية (الأردن: دار اليفى العلمية, 2013).

23 H. Douglas Brown, Principle of Language Learning and Teaching (New York: Prentice-
} Hall). 
intervention of researchers. Survey research is conducted using structured questions in the form of questionnaires, which are asked to many people, then all answers obtained by researchers are recorded, processed, and analyzed. ${ }^{24}$

\section{Research Step}

The steps taken are 1) reading literature related to Arabic speaking teaching materials and teaching Arabic speaking skills, 2) observing the learning process of speaking skills at several Arabic Language Education Study Programs, 3) determining the type of survey, 4) determining the sample target, 5) preparing instruments for analyzing the needs of students, 6) preparing structured interview instruments for lecturers, 7) analyzing survey results, 8) translating survey results.

\section{Data Sources}

There are 2 data sources from this study, namely document data sources and personal data sources. The document data source comes from Al-Arabiyah Baina Yadaik's teaching book (ABY), Al-Arabiyah lil 'Alam (ALA) and Al-Arabiyah lin Nasyiin (ALIN). Source of personal data comes from the analysis of the needs of students and the results of the situation analysis of lecturers who speak Arabic.

\section{Participant (Subject) Characteristics}

Participants in this study were 97 first semester students of the Arabic Language Education Study Program at higher education in Indonesia, and lecturers who supported Arabic speaking skills for beginners at tertiary institutions.

\section{Instruments}

To get data following what was formulated in the problem formulation above, the instrument was needed in the form of a checklist containing questions based on theoretical studies on the preparation of teaching materials. The instrument was in the form of a needs analysis questionnaire. According to Brown, needs analysis refers to the activities carried out in gathering information about the whole learning process that is used as a basis for the development of syllabi, teaching materials, or curriculum. ${ }^{25}$ Richard mentioned that needs analysis is a

\footnotetext{
${ }^{24}$ Bambang Prasetyo, Metode Penelitian Kuantitatif (Jakarta: RajaGrafindo Persada, 2005).

${ }^{25}$ Brown.
} 
procedure that is carried out to gather information about student needs and what students want to know. ${ }^{26}$

\section{Result and Discussion}

\section{Result of Need Analysis}

Needs analysis aims to get the direction of learning objectives, student needs, and analyze the principal teaching material to be developed. The needs analysis was carried out using an instrument that had been completed by 97 first semester students in the Arabic Language Study Program at Higher Education Institutions in Indonesia. The needs analysis is carried out with the approach of the criteria of necessities, lack and the want of students towards teaching materials.

\section{Requirements Analysis of the criteria of necessities}

Aiming to get information on what students must know and do during and after participating in learning. In getting this information, researchers used a questionnaire. Researchers provide 4 alternative answers, namely very often, often, sometimes and never. From these 4 alternative answers, the researcher focuses on the highest percentage score that can be seen in the following table:

Table 1. Criteria that must be done by Students

\begin{tabular}{llll}
\hline No & \multicolumn{1}{c}{ Criteria of Mandatory } & Score & Category \\
\hline 1. & $\begin{array}{l}\text { Review the topic of discussion independently or } \\
\text { in groups }\end{array}$ & $63,9 \%$ & Sometimes \\
\hline 2. & Try speaking exercises to hone speaking skills & $45,4 \%$ & Sometimes \\
\hline 3. & $\begin{array}{l}\text { Actively explore the knowledge and skills of } \\
\text { speaking Arabic from sources that can be easily } \\
\text { obtained }\end{array}$ & $48,5 \%$ & Often \\
\hline
\end{tabular}

After searching, the initial assumption of the results of this analysis is the learning resources used in learning to speak Arabic only through teaching materials from the Middle East, and the lack of individual training in learning resources makes students less practice outside of class hours. Generally, students use learning resources that are easily obtained through the internet. Through this student activity, lecturers should be able to facilitate the provision of training assignments that utilize learning resources in addition to existing teaching materials. Easy-to-get learning resources are needed by students, so

${ }^{26}$ Jack C. Richards and Manel Lacorte, Book Reviews : Curriculum Development in Language Teaching, RELC Journal (United States of America: Cambridge University Press, 2007), XXXIII <https://doi.org/10.1177/003368820203300112>. 
lecturers need to prepare teaching materials that can be used by students independently or in groups.

\section{Analysis of the needs of the difficulty criteria (lack)}

Aiming to get the types of needs relating to what students already know but still become difficulties or obstacles in learning.

Table 2. Criteria for Difficulties that Occur

\begin{tabular}{cllc}
\hline No & \multicolumn{1}{c}{ Criteria for Difficulty } & Score & Category \\
\hline 1. & Difficulty in sounding certain phonemes in Arabic & $52,6 \%$ & Often \\
\hline 2. & $\begin{array}{l}\text { Difficulty in choosing vocabulary in certain contexts } \\
\text { when asked to speak Arabic }\end{array}$ & $54,6 \%$ & Often \\
\hline 3. & Difficulty in making simple sentences in Arabic & $53,6 \%$ & Sometimes \\
\hline 4. & Difficulty in answering spoken questions in Arabic & $41,2 \%$ & Sometimes \\
\hline 5. & $\begin{array}{l}\text { Difficulties in asking questions to lecturers about } \\
\text { material that is not yet understood }\end{array}$ & $45,4 \%$ & Often \\
\hline 6. & $\begin{array}{l}\text { Difficulty in establishing communication with } \\
\text { colleagues using Arabic }\end{array}$ & $50,2 \%$ & Often \\
\hline 7. & $\begin{array}{l}\text { Difficulty in communicating outside the classroom } \\
\text { using Arabic }\end{array}$ & $47,4 \%$ & Often \\
\hline
\end{tabular}

The results of the analysis of the needs of the criteria of difficulty (lack) indicate that the problem that very often occurs in students is the difficulty in choosing vocabulary, and difficulty in communicating outside the classroom. In supporting vocabulary mastery, teaching materials used must meet the characteristics of teaching aids that contain colors, sizes according to and have an impact on learning. ${ }^{27}$ Vocabulary is a key component of language learning, failure to master vocabulary causes weaknesses in other language skills such as writing, listening and reading.

\section{Analysis of needs wants criteria (want)}

Aim to find out the views of students about what they want from teaching materials. The instrument for analyzing teaching material requirements for contextual Arabic speaking skills was designed to include six parts, namely the learning objectives, the components of teaching materials, and themes. Researchers provide 3 alternative answers to students to answer the statement given, they need, need and don't need. The following results are obtained:

a) Analyze the needs of the want criteria in terms of learning objectives,

\footnotetext{
${ }^{27}$ Irma Martiny Md. Yasim and others, 'The Use of Teaching Aids in the Teaching and Learning of Arabic Language Vocabulary', Creative Education, $07.03 \quad$ (2016), $443-48$ <https://doi.org/10.4236/ce.2016.73044>.
} 
Table 3. Criteria for want in terms of learning objectives

\begin{tabular}{|c|c|c|c|}
\hline No & $\begin{array}{c}\text { Criteria of Want } \\
\text { in Terms of Learning Objectives }\end{array}$ & Score & Category \\
\hline 1. & $\begin{array}{l}\text { Able to pronounce Arabic sounds especially sounds that } \\
\text { have no equivalent in Indonesian with clear articulation }\end{array}$ & $62,9 \%$ & Really Needed \\
\hline 2. & $\begin{array}{l}\text { Able to recite the sounds of the Arabic letters that are } \\
\text { adjacent to its makhraj }\end{array}$ & $67 \%$ & Really Needed \\
\hline 3. & Able to distinguish long and short vowel pronunciation & $73,2 \%$ & Really Needed \\
\hline 4. & $\begin{array}{l}\text { Able to speak using the right intonation, rhythm, facial } \\
\text { expressions, and body gestures }\end{array}$ & $57,7 \%$ & Really Needed \\
\hline 5. & $\begin{array}{l}\text { Able to develop gradual growth in communication, starting } \\
\text { from being accustomed to choosing vocabulary and } \\
\text { sentences according to context. }\end{array}$ & $66 \%$ & Really Needed \\
\hline 6. & $\begin{array}{l}\text { Being able to express ideas, ideas, thoughts, and feelings } \\
\text { into spoken Arabic language }\end{array}$ & $55,7 \%$ & Really Needed \\
\hline 7. & $\begin{array}{l}\text { Being able to express ideas with logical sentences in various } \\
\text { situations }\end{array}$ & $56,7 \%$ & Really needed \\
\hline 8. & $\begin{array}{l}\text { Able to talk and communicate outside of class hours with } \\
\text { vocabulary commonly used in daily communication }\end{array}$ & $63,9 \%$ & Really Needed \\
\hline
\end{tabular}

Looking at the results of the needs analysis of the desirability criteria in terms of learning objectives, it was found that the main goal desired by students is the desire to start at the smallest level, namely sound. The desire to be taught and pay attention to their ability to distinguish long and short vowel sounds, the sound of letters that its makhraj that are close together and different from Indonesian, should be considered.

b) Analysis of the need for the criteria of desire (want) components of the desired material only

Table 4. Criteria of want in Terms of Teaching Material Components

\begin{tabular}{clcc}
\hline No & \multicolumn{1}{c}{$\begin{array}{c}\text { Criteria of Want in Terms of Teaching Material } \\
\text { Components }\end{array}$} & Score & Category \\
\hline 1. & Contains competencies for each unit/meeting & $54,6 \%$ & Needed \\
\hline 2. & $\begin{array}{l}\text { Have exercises/tests/assessments for each } \\
\text { unit/discussion }\end{array}$ & $49,5 \%$ & Really Needed \\
\hline 3. & $\begin{array}{l}\text { Have an evaluation at the end of the } \\
\text { chapter/discussion unit }\end{array}$ & $50,5 \%$ & Needed \\
\hline 4. & Having renewal of material that suits current needs & $52,6 \%$ & Really Needed \\
\hline 5. & $\begin{array}{l}\text { Having a variety of conversations in each } \\
\text { chapter/discussion unit }\end{array}$ & $55,7 \%$ & Really Needed \\
\hline 6. & Using terms or vocabulary that is often used every day & $69,1 \%$ & Really Needed \\
\hline 7. & The topics discussed can reflect daily communication & $58,8 \%$ & Really Needed \\
\hline 8. & $\begin{array}{l}\text { Teaching materials are easily understood } \\
\text { independently or in groups }\end{array}$ & Really Needed \\
\hline 9. & $\begin{array}{l}\text { Having examples of conversations that can be } \\
\text { developed independently or in groups }\end{array}$ & Really Needed \\
\hline
\end{tabular}

There is a relationship between the difficulties that often occur with students with the desire of students for teaching materials to be developed. Generally, students want informative teaching materials that provide terms and vocabulary regarding daily 
communication, teaching materials are easily understood and developed independently or in groups, and have variations in daily communication. Current technology has a significant impact on accompanying the design of developed teaching materials. Technology can be integrated into different ways in the language learning environment, from being a communication tool to becoming a tutor. Several studies have been carried out to confirm the use of technology in teaching Arabic pronunciation.

c) Analysis of the need for the criteria of want regarding the theme of the desired teaching material

Table 6. Criteria of want in Terms of the Theme of Teaching Materials

\begin{tabular}{|c|c|c|c|}
\hline \multirow{2}{*}{$\begin{array}{l}\text { No } \\
1 .\end{array}$} & \multicolumn{2}{|c|}{$\begin{array}{l}\text { Criteria of Want } \\
\text { in terms of the theme of teaching materials }\end{array}$} & \multirow{2}{*}{$\begin{array}{c}\text { Category } \\
95,9 \% \\
\end{array}$} \\
\hline & Self Introduction & التعارف & \\
\hline 2. & Family and daily life & الأسرة و الحياة اليومية & $89,7 \%$ \\
\hline 3. & Residence & السكن & $86,6 \%$ \\
\hline 4. & Hobby & الهواية & $80,4 \%$ \\
\hline 5. & Food and Drinks & الطعام و الشرب & $77,3 \%$ \\
\hline 6. & Public Transportation & المواصلات & $72,2 \%$ \\
\hline 7. & Social Media & الوسائل الاجتماعية & $67 \%$ \\
\hline 8. & Coursework & الواجبات & $61,9 \%$ \\
\hline 9. & Handphone & 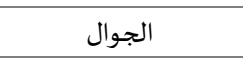 & $60,8 \%$ \\
\hline 10. & Computer and Laptop & الحاسوب & $60,8 \%$ \\
\hline 11. & Student organizations & منظمة الطلاب & $60,8 \%$ \\
\hline 12. & Sports & الرياضة & $56,7 \%$ \\
\hline 13. & Shopping & التسوق & $47,4 \%$ \\
\hline 14. & Clothes & 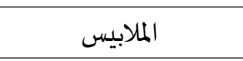 & $45,4 \%$ \\
\hline 15. & Canteen & 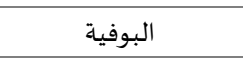 & $40,2 \%$ \\
\hline 16. & Scholarships & المنحة الدراسية & $39,2 \%$ \\
\hline 17. & Movies and Music & الأفلام و الموسيقى & $36,1 \%$ \\
\hline
\end{tabular}

When looking at the results of the analysis of the need for discussion themes, students generally want a contemporary theme that is close to their daily communication. So, it is better if the design of teaching materials that will be developed can facilitate the needs of students towards the theme of the discussion and prioritize customs and culture. ${ }^{28}$

Broadly speaking, it can be concluded that the things that are needed by students who are studying Arabic as a foreign language are related to phonetic aspects, socio-

28 Tariq Elyas and Michelle Yvette Picard, 'Teaching and Moral Tradition in Saudi Arabia: A Paradigm of Struggle or Pathway Towards Globalization?', Procedia - Social and Behavioral Sciences, 47 (2012), 1083-86 <https://doi.org/10.1016/j.sbspro.2012.06.782>. 
cultural aspects, aspects of theme and types of exercises. Therefore, teaching materials developed need to use an approach that is on target.

\section{Situation Analysis Results}

From the results of interviews with lecturers, the gap between the needs of lectures and teaching materials in Arabic speaking skills, among others:

1. The teaching material used is output from the Middle East, to get the original documents is quite difficult. Students currently copy more/duplicate the book, which sometimes makes teaching materials difficult to read or images difficult to understand because of unclear copy results.

2. Another disadvantage lies in the use of Arabic fusha which is used too high and is less familiar with students. In terms of themes, the general context of communication is highly set in Arabic culture. This context is quite difficult for students to match with the Indonesian context.

3. The high cultural differences and language attitudes between the Middle East and not the Middle East can create gaps in language learning.

\section{Characteristics of Teaching Materials of Arabic Speaking Skills in Higher} Education

The results of the needs analysis and situation analysis provide a clear picture of the characteristics of Arabic speaking skills required by the culture and curriculum in Indonesia. The development of teaching materials in Arabic speaking skills in higher education requires constant preparation to ensure that operational standards and guidelines for successful learning outcomes. Effectiveness learning depends on the quality of planning teaching materials and the level of implementation. ${ }^{29}$ These characteristics to develop material teaching include:

\section{Purpose}

The aim of learning beginner Arabic for Indonesian speakers, can be implemented in the development of teaching materials as follows: 1) Speaking conversations with clear articulation, 2) Distinguishing long vowels and short vowels, 3) Expressing thoughts with reasonable speed of speech, with tone, the right rhythm and intonation in the form of paired communication, 4) facial and body gestures when communicating in pairs, 5) Using the right vocabulary in composing and linking words 
into sentences when communicating, 6) Linking a story through the role of media images or other media, 7) Manage communication strategies, 8) Integrate conversations in textbooks with other sources of information technology, and 9) Create conversations into a dialogue that is suitable for daily communication in pairs or groups.

\section{Phonetics}

One of the concerns of students when studying Arabic is because Arabic has orthographic depth, which means it has "shallow" and "deep" or short vocal and long vocal orthography. For this reason, lecturers need to teach differences in the pronunciation of short and long vowels that can change the meaning. ${ }^{30}$ Teaching material developed for students of Arabic as a second language should be preceded by an introduction to the basics of Arabic, for example from articulation, listening and imitating lecturers, as well as illustrated vocabulary. ${ }^{31}$ In the first and second meetings, students are accustomed to listening and speaking. When students absorb what is said by the lecturer, students are asked to repeat every day to identify sounds, point of articulation, find out the differences in vowel length and short, recognize the striking differences between Arabic and Indonesian sounds. The type of vocabulary on the material/topic being studied does not start from the alphabet a, b, c, d but starts from the easier pronunciation such as a, b, t, d, r, s, f, q, k, l, m, n, h, w, y go to more difficult

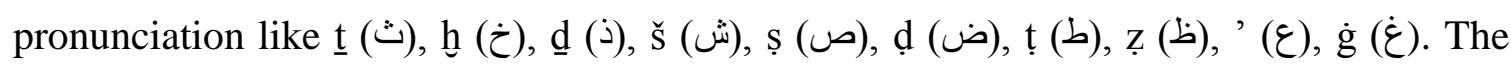
sounds are distributed into vocabulary that has meaning according to the topic.

\section{Theme}

The age of globalization today is helping greatly in the spread of languages and encourages modern generations to acquire the skill of learning more than one source. ${ }^{32}$ Themes and topics should be chosen at the latest, according to curriculum development, according to global developments, and according to the level of student ability. ${ }^{33}$ Avoid outdated themes such as post offices, libraries, parks, and so on. At present the themes

\footnotetext{
${ }^{29}$ Adam Sirajudeen and AbdulWahid Adebisi, 'Teaching Arabic as a Second Language in Nigeria', $\begin{array}{lllll}\text { Procedia - Social and Behavioral } & \text { Sciences, } 66 & \text { (2012), } & \text { 126-35 }\end{array}$ <https://doi.org/10.1016/j.sbspro.2012.11.254>.

30 Yasmine Kataw, 'Teaching Arabic as a Foreign Language: The Role of Communicative Competence, Pragmatics, and Literacy', 2016.

${ }^{31}$ Basma Ahmad Sedki Dajani and Fatima Mohammad Amin Omari, 'A Critical Study of Three Textbooks for Teaching Arabic to Non-Native Speakers', Procedia - Social and Behavioral Sciences, 114 (2014), 476-81 <https://doi.org/https://doi.org/10.1016/j.sbspro.2013.12.732>.

32 Dajani, Mubaideen, and Omari.

${ }^{33}$ Kholisin.
} 
that are needed by students regarding social media, mobile phones, computers, and laptops.

\section{Socio-cultural}

When designing educational materials, it is important to be familiar with the cultural issues that must be taken. ${ }^{34}$ Someone who studies Arabic as a certain foreign language will not be able to understand it well without understanding the culture of the people. In connection with this, the contents of Arabic teaching materials that are developed should be based on Arabic learning concepts and theories, the latest developments, and the results of empirical research conducted in the field of Arabic language science. These factors are considered as strong factor in motivating and encouraging the students to learn the Arabic language in the best manner. ${ }^{35}$ As for content harmony, the contents of Arabic teaching materials are adjusted to the system of values and philosophy of life that applies in the country and society in the school environment. ${ }^{36}$ If in teaching materials published by the Middle East students try to learn Arabic language and culture, in the teaching materials developed can also add ideas by introducing Indonesian culture to Arabic speakers. This idea, for example, is included in the form of food dialogue, clothing, exchange rates, and so on.

\section{Exercise}

If the existing teaching materials direct students to memorize dialogue, exercises in teaching materials can be systematically developed and tiered as follows: 1) Introducing yourself by imitating examples, 2) Doing questions and answers by imitating examples, 3) Arranging 4,3,2 pieces words become a sentence, 4) Answering questions according to personal conditions, 5) Doing questions and answers, using 4 pictures and keywords, 6) Performing a role by designing dialogue according to the group couple's agreement, 7) Doing questions and answers by paying attention to grammar simple, 8) Answering questions based on pictures, 9) Doing questions and answers based on pictures, 10) Telling stories to friends based on questions in teaching material, and 11) Arranging conversations based on contexts determined by teaching materials.

\footnotetext{
${ }^{34}$ Laeth S. Nasir and Arwa K. Nasir, 'Introducing Arabic Language Patient Education Materials in Jordan', Patient Education and Counseling, $60.2 \quad$ (2006), 142-45 <https://doi.org/10.1016/j.pec.2004.12.006>.

${ }^{35}$ Rawya Jamous and Abdul Rahman Chik, 'Teaching Arabic for Cultural Purposes: A Case Study of Francophone Program of Arabic at Aleppo University', Procedia - Social and Behavioral Sciences, 66 (2012), 37-45 <https://doi.org/https://doi.org/10.1016/j.sbspro.2012.11.245>.
} 


\section{Step}

The technique of presenting teaching materials should begin with information on the list of competencies that will be obtained by students after studying one unit or one meeting. This list of competencies is not found in teaching materials from the Middle East. Then the teaching material begins with dialogue. In the learning process, first, the lecturer utters dialogue, or plays dialogue through a tape recorder and then imitated by students. Students are not allowed to see the written form of the conversation so that their attention is fully concentrated in the sound of dialogue that is heard. Second, the repetition of istima' (listening) while understanding the contents of the dialogue, students are only allowed to see pictures of vocabulary they do not know. Third, students are allowed to read the dialogue text. Fourth, after the contents of the hiwar are understood, then it is followed up with an introduction to basic grammar. And finally, students are asked to do exercises following the direction of teaching materials. ${ }^{37}$

\section{Visualization}

Visualization of teaching materials for Arabic speaking skills is divided into 4 things, namely realistic, analogical, organizational, and transformational. ${ }^{38}$ Realistically, objects are displayed in real terms, not with abstract images or silhouettes. For example in vocabulary "قط", The picture shown is a cat, not a silhouette or abstract image. Analogic, ie messages, concepts or topics delivered to students visualized similar or similar to those described. Organizational namely displaying diagrams or related structures, for example when studying Arabic grammar, verbs when drawn using charts will be easier for students to understand. Transformational, namely visualizing change based on the context of time and place. For example, in teaching changes to verbs based on time can be described in tabular form.

\section{Conclusion}

Teaching materials that are generally developed and widely used for learning Arabic speaking skills in universities in Indonesia generally come from the Middle East.

\footnotetext{
${ }^{36}$ Muhammad Syaifullah and Nailul Izzah, 'Kajian Teoritis Pengembangan Bahan Ajar Bahasa Arab', Arabiyatuna : Jurnal Bahasa Arab, 3.1 (2019), 127 <https://doi.org/10.29240/jba.v3i1.764>.

37 Rahmaini, 'Strategi Pembelajaran Maharah Kalam Bagi Non-Arab', Ihya Al-Arabiyah: Jurnal Pendidikan Bahasa Dan Sastra Arab, 1.2 (2015), 227-33.

38 Sharon Smaldino, Instructional Technology \& Media for Learning (Jakarta: Kencana Prenada Media, 2011).
} 
Teaching material originating from the Middle East is not specifically just for teaching Arabic speaking skills, but rather for comprehensive language skills namely listening, speaking, reading and writing. Not many teaching materials have been found that specifically can be used for Arabic speaking skills. Learning Arabic as a second language for Indonesian speakers has its difficulties. Especially, teaching materials from the Middle East do not provide a sufficient portion of the phonetic accuracy aspect. Because teaching material from the Middle East is used for foreign speakers/students who are studying Arabic in the Middle East region. On the other hand, the exercises contained in teaching materials are monotonous, and lead students to memorize dialogue. Memorization is not part of productive skills, but rather supporting vocabulary. This problem requires the awareness of teachers of Arabic speaking skills to develop a teaching material that is following the curriculum in Indonesia, the times and according to the needs of students. Some of the principles outlined in this study can be used as guidelines in developing teaching materials that are appropriate to the needs of Arabic language students at higher education in Indonesia. For developers of teaching materials for such lecturers or other researchers, the results of this study can be used as a reference, especially research and development of teaching materials for Arabic speaking skills.

\section{Acknowledgment}

Thank you to the Indonesia Endowment Fund for Education (LPDP - Lembaga Pengelola Dana Pendidikan) of the Republic of Indonesia for providing support in the form of funding so that this research can take place.

\section{References}

Al-Naqah, Mahmud Kamil, تعليم اللغة العربية لناطقين بالغة الأخرى: أسوسه، دداخله، طروق تدريسه (مكة) المكرمة: جامعة الأم القرى)

Amerian, Majid, and Sajjad Pouromid, 'Language Teachers' Beliefs on Materials Use And Their Locus Of Control: Case-Studies From Iran And Japan', International Journal of Applied $\quad$ Lingustics, $\quad 7.3 \quad$ (2018) <https://doi.org/http://dx.doi.org/10.17509/ijal.v7i3.9808>

Brown, H. Douglas, Principle of Language Learning and Teaching (New York: Prentice Hall)

Dajani, Basma Ahmad Sedki, Salwa Mubaideen, and Fatima Mohammad Amin Omari, 'Difficulties of Learning Arabic for Non-Native Speakers', Procedia - Social and 
Behavioral Sciences, $\quad 114 \quad$ (2014), $\quad$ 919-26 <https://doi.org/10.1016/j.sbspro.2013.12.808>

Dajani, Basma Ahmad Sedki, and Fatima Mohammad Amin Omari, 'A Critical Study of Three Textbooks for Teaching Arabic to Non-Native Speakers', Procedia - Social and Behavioral Sciences, $114 \quad$ (2014), 476-81 <https://doi.org/https://doi.org/10.1016/j.sbspro.2013.12.732>

Elyas, Tariq, and Michelle Yvette Picard, 'Teaching and Moral Tradition in Saudi Arabia: A Paradigm of Struggle or Pathway Towards Globalization?', Procedia Social and Behavioral Sciences, 47 (2012), 1083-86 <https://doi.org/10.1016/j.sbspro.2012.06.782>

Fadhlullah, Muhammad Rajab, الاتجاهات التربيوية الدعاصرة في تدربي اللغة العربية, ed. by عالمة)

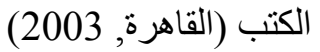

Ghani, Kamarulzaman Abd., Nik Mohd Rahimi Nik Yusof, Harun Baharuddin, Hamidah Yamat, Zamri Ahmad, and Ibtisam Abdullah, 'Development of a Learning Module on Arabic Language Skills Outside of the Classroom', Procedia - Social and Behavioral Sciences, $18 \quad$ (2011), $154-62$ <https://doi.org/https://doi.org/10.1016/j.sbspro.2011.05.023>

Graves, Kathleen, Designing Language Courses: A Guide for Teachers (Canada: Heinle \& Heinle Publishers, 2000)

Hendri, Muspika, 'Pembelajaran Keterampilan Berbicara Bahasa Arab Melalui Pendekatan Komunkatif', POTENSIA: Jurnal Kependidikan Islam, 3.2 (2017), 196 <https://doi.org/10.24014/potensia.v3i2.3929>

Istitih, Samir Syarif, ‘علم اللغة التعلمي, (الأردن: دار العمال, pp. 141-42

Jamous, Rawya, and Abdul Rahman Chik, 'Teaching Arabic for Cultural Purposes: A Case Study of Francophone Program of Arabic at Aleppo University', Procedia Social and Behavioral Sciences, 66 (2012), 37-45 <https://doi.org/https://doi.org/10.1016/j.sbspro.2012.11.245>

Kataw, Yasmine, 'Teaching Arabic as a Foreign Language: The Role of Communicative Competence, Pragmatics, and Literacy', 2016

Kholisin, 'Pembelajaran Kalam Berbasis Phonetic Accuracy Untuk Meningkatkan Kemampuan Berbicara Bahasa Arab', Jurnal Bahasa, Sastra, Seni Dan Pengajaran, 43.2 (2015), 143-53

Mahmoodi, Mohammad-Hadi, and Ismail Moazam, 'Willingness to Communicate (WTC) and L2 Achievement: The Case of Arabic Language Learners', Procedia Social and Behavioral Sciences, $98 \quad$ (2014), $1069-76$ <https://doi.org/https://doi.org/10.1016/j.sbspro.2014.03.518>

Manshur, Mahmud, الإستعاع والحوار فنون الدقابلة المثالية (الأردن: دار اليفى العلمية, 2013)

Mendelsohn, D.J, and J Rubin, A Guide for The Teaching Of Second Language Listening 
(Dominie Press, 1995)

Nasir, Laeth S., and Arwa K. Nasir, 'Introducing Arabic Language Patient Education Materials in Jordan', Patient Education and Counseling, 60.2 (2006), 142-45 <https://doi.org/10.1016/j.pec.2004.12.006>

Prasetyo, Bambang, Metode Penelitian Kuantitatif (Jakarta: RajaGrafindo Persada, 2005)

Prastowo, Andi, Panduan Kreatif Membuat Bahan Ajar Inovatif (Yogyakarta: Diva Press, 2016)

Rahmaini, 'Strategi Pembelajaran Maharah Kalam Bagi Non-Arab', Ihya Al-Arabiyah: Jurnal Pendidikan Bahasa Dan Sastra Arab, 1.2 (2015), 227-33

Rasyid, Yumna, and Puti Zulharby, 'Developing Syllabus of Arabic Language Productive Competence Based on Content Language Integrated Learning (Clil)', Ijer - Indonesian Journal of Educational Review, 4.1 (2017), 153 <https://doi.org/10.21009/ijer.04.01.15>

Richard, Jack C., and Willy A Renandya, Methodology in Language Teaching: An Anthology of Current Practice (New York: Cambridge University Press, 2002)

Richards, Jack C., and Manel Lacorte, Book Reviews: Curriculum Development in Language Teaching, RELC Journal (United Stated of America: Cambridge University Press, 2007), XXXIII <https://doi.org/10.1177/003368820203300112>

Roviin, Roviin, 'Analisis Buku Teks Al 'Arabiyah Li Al Nasyi’in Karya Mahmud Ismail Shini, Dkk', Jurnal Al Bayan: Jurnal Jurusan Pendidikan Bahasa Arab, 10.01 (2018), 36-53 <https://doi.org/10.24042/albayan.v10i01.2594>

Sirajudeen, Adam, and AbdulWahid Adebisi, 'Teaching Arabic as a Second Language in Nigeria', Procedia - Social and Behavioral Sciences, 66 (2012), 126-35 <https://doi.org/10.1016/j.sbspro.2012.11.254>

Smaldino, Sharon, Instruksional Technology \& Media for Learning (Jakarta: Kencana Prenada Media, 2011)

Syaifullah, Muhammad, and Nailul Izzah, 'Kajian Teoritis Pengembangan Bahan Ajar Bahasa Arab', Arabiyatuna: Jurnal Bahasa Arab, 3.1 (2019), 127 <https://doi.org/10.29240/jba.v3i1.764>

Wahab, Muhbib Abdul, 'Standarisasi Kurikulum Pendidikan Bahasa Arab Di Perguruan Tinggi Keagamaan Islam Negeri', Jurnal Pedidikan BAhasa Arab Dan $\begin{array}{llll}\text { Kebahasaaraban, } & 3.1 & \text { (2016), }\end{array}$ <https://doi.org/http://dx.doi.org/10.15408/a.v3i1.3187>

Yaqub, Muhammad Tunde, 'Developing Speaking Skill in Arabic Learners: A Proposal for Integration of Product and Proces Approaches', European Scientific Journal, 8.29 
Yasim, Irma Martiny Md., Maimun Aqsha Lubis, Zaid Arafat Mohd Noor, and Mohd Yusri Kamarudin, 'The Use of Teaching Aids in the Teaching and Learning of Arabic Language Vocabulary', Creative Education, 07.03 (2016), 443-48 <https://doi.org/10.4236/ce.2016.73044>

Zedan, Ashraf M., Fakhrul Adabi Bin Abdul Kadir, Mouhammed Bin Yusof, Yusmini Binti Md Yusoff, Norrodzoh Binti Hj Siren, Roslan Bin Mohamed, and others, 'The Role of Language in Education: Arabic as Case Study', Procedia - Social and $\begin{array}{llll}\text { Behavioral } \quad \text { Sciences, } & 70 & \text { (2013), }\end{array}$ <https://doi.org/10.1016/j.sbspro.2013.01.151> 